\title{
THE ROLE OF PHYSICAL ELEMENT SETTINGS ON THE ACTIVITIES OF THE URBAN TOURISM VILLAGE STUDY OBJECT: KAMPUNG LAWAS MASPATI AND KAMPUNG PELANGI KENJERAN
}

\author{
${ }^{1}$ Dionisius Arief Anjasmoro, ${ }^{2}$ Dr. Y. Basuki Dwisusanto, Ir., M.Sc \\ ${ }^{1}$ Student in the Bachelor's (S-1) Study Program in Architecture \\ at Parahyangan Catholic University \\ ${ }^{2}$ Senior lecturer in the Bachelor's (S-1) Study Program in Architecture \\ at Parahyangan Catholic University
}

\begin{abstract}
Indonesia has a variety of urban tourism village scattered in various regions. The tourism village has various themes according to the character of the are and the residents of the village. Such as Batik Village, Ceramic Village, Rainbow Village, etc. The presence of the concept of an urban tourism village doesn not only occur in Indonesia, but also occurs in various other countries such as Gamcheon Culture Village in Korea, Chefchaouen in Marocco, Marsaxlokk Village in Malta, etc. With the presence of the concept of tourism village, it provides novelty for both humans (tourist and villagers) as the users of space accompanied by their activities.

Based on these problems the authors are interested in conducting this research. This research will discuss about what is meant by a tourist village, how tourism activities occur in the two study objects and how architecture as a physical element plays a role in the activities in it. The purpose of this study is to describe how far a village called a tourist village is feasible as a tourist place by introducing the tourism criteria, what are the criteria for a village to be called a tourist village. This research is a descriptive qualitative research, using Kampung Lawas Maspati and Kampung Pelangi Kenjeran as objects of study to be compared based on the tourism criteria itself, to further examine how the physical (architectural) element settings play a role in accommodating tourism activities in the village itself. So that how far the two objects of study meet the existing tourist criteria so that they are feasible as tourist attractions. With this research, it is hoped that it can provide an understanding of what is meant by a tourist village and the importance of the role of architecture in realizing the tourism village it deserves.

The results of the research show that the physical elements in Kampung Lawas Maspati meet the three criteria that a tourism village needs to have and there are tourism activities organized by local village managers, while Kampung Pelangi Kenjeran has not fulfilled existing tourism criteria, the availability of physical elements in Kampung Pelangi Kenjeran is very minimal. This proves that the term "tourism" in Pelangi Kenjeran village is still not appropriate as it should be.
\end{abstract}

Key Words: setting, physical elements, activity, urban tourim village

\section{PERAN SETTING ELEMEN FISIK TERHADAP AKTIVITAS PADA KAMPUNG WISATA OBJEK STUDI: KAMPUNG LAWAS MASPATI DAN KAMPUNG PELANGI KENJERAN SURABAYA}

\author{
${ }^{1}$ Dionisius Arief Anjasmoro, ${ }^{2}$ Dr. Y. Basuki Dwisusanto, Ir., M.Sc \\ ${ }^{1}$ Mahasiswi S1 Program Studi Arsitektur Universitas Katolik Parahyangan \\ ${ }^{2}$ Dosen Pembimbing S1 Program Studi Arsitektur Universitas Katolik Parahyangan
}

\footnotetext{
${ }^{1}$ Corresponding Author: dariefanjasmoro@gmail.com
} 


\title{
The Role Of Physical Element Settings On The Activities Of The Urban Tourism Village Study Object: Kampung Lawas Maspati And Kampung Pelangi Kenjeran
}

\begin{abstract}
Abstrak - Indonesia memiliki beragam kampung wisata yang tersebar di berbagai wilayah. Kampung wisata tersebut memiliki tema yang beragam sesuai dengan karakter wilayah dan warga kampungnya. Sebut saja seperti kampung batik, kampung keramik, dan kampung pelangi, dan lain sebagainya. Hadirnya konsep kampung wisata juga tidak hanya terjadi di Indonesia, tapi juga terjadi di berbagai negara lain seperti Gamcheon Culture Village di Korea, Chefchaouen di Maroko, Marsaxlokk Village di Malta, dan lainnya. Dengan hadirnya konsep wisata pada suatu kampung, memberikan kebaruan baik manusia (wisatawan dan warga kampung) sebagai pengguna ruang disertai dengan aktivitasnya.

Berdasarkan pemaparan tersebut, penulis tertarik untuk meneliti bagaimana dengan hadirnya kampung wisata ini memberikan pengaruh secara arsitektural pada kampung wisata. Penelitian ini akan membahas mengenai apa yang dimaksud kampung wisata, bagaimana terjadinya aktivitas wisata pada kedua objek studi berikut bagaimana arsitektur sebagai elemen fisik berperan terhadap aktivitas di dalamnya. Tujuan dari penelitian ini adalah menguraikan seberapa jauh sebuah kampung yang disebut kampung wisata layak sebagai tempat wisata dengan memperkenalkan kriteria wisata apa kriteria suatu kampung dapat disebut sebagai kampung wisata. Penelitian ini merupakan penelitian kualitatif deskriptif, menggunakan Kampung Lawas Maspati dan Kampung Pelangi Kenjeran sebagai objek studi untuk dikomparasi berdasarkan kriteria wisata itu sendiri, untuk selanjutnya diteliti bagaimana setting elemen fisik (arsitektur) berperan dalam mengakomodir aktivitas wisata pada kampung itu sendiri. Sehingga dapat seberapa jauh kedua objek studi tersebut memenuhi kriteria wisata yang ada sehingga layak sebagai tempat wisata. Dengan adanya penelitian ini diharapkan dapat memberikan pemahaman apa yang dimaksud dengan kampung wisata dan pentingnya peran arsitektur dalam mewujudkan kampung wisata yang selayaknya.

Dari hasil penelitian menunjukan bahwa elemen fisik pada Kampung Lawas Maspati memenuhi tiga kriteria yang perlu dimiliki kampung wisata dan terdapat aktivitas wisata yang diselenggarakan oleh pengelola kampung setempat, sedangkan Kampung Pelangi Kenjeran belum memenuhi keriteria wisata yang ada, ketersediaan elemen fisik pada Kampung Pelangi Kenjeran pun sangat minim. Hal ini membuktikan adanya istilah "wisata" pada kampung Pelangi Kenjeran masih belum sesuai sebagai mana mestinya.
\end{abstract}

Kata Kunci: setting, elemen fisik, aktivitas, kampung wisata

\section{PENDAHULUAN}

Indonesia memiliki beragam kampung wisata yang tersebar di berbagai wilayah. Kampung wisata tersebut memiliki tema yang beragam sesuai dengan karakter wilayah dan warga kampungnya. Sebut saja seperti kampung batik, kampung keramik, kampung kreatif, kampung pelangi, dan kampung wisata yang lain. Kampung batik memiliki ciri warga kampungnya yang mayoritas berprofesi sebagai penghasil batik, di mana kegiatan membatik dan batik yang dihasilkan menjadi daya tarik tersendiri bagi wisatawan yang berkunjung. Adapun kampung keramik, di mana warga kampung yang mayoritas berprofesi sebagai pengrajin keramik dengan segala kegiatan yang dilakukan dan keramik yang dihasilkan menjadi daya tarik tersendiri bagi wisatawan. Begitu juga dengan berbagai jenis kampung wisata yang lainnya. Diselenggarakannya kampung wisata memiliki berbagai tujuan, seperti pada kampung kreatif yaitu membangun perekonomian masyarakat lokal melalui pengembangan usaha kreatif dengan harapan dapat menarik wisatawan datang ke tempat tersebut.

Selain keberadaan kampung-kampung wisata tersebut, di Indonesia juga terdapat kampung Pelangi yang juga sering menjadi destinasi wisata. Kampung Pelangi di Indonesia sendiri terdapat di berbagai tempat, seperti Kampung Jodipan di Malang, Kampung Pelangi di Semarang, Kampung Pelangi Kenjeran di Surabaya, Kampung Pelangi Muara Kamal di Jakarta, dan sebagainya. Dari berbagai kampung pelangi yang ada, ciri-ciri secara umum dari kampung pelangi itu sendiri yaitu memiliki warna bangunan yang beragam, namun umumnya memiliki latar belakang sebagai kampung kumuh yang mendapatkan program untuk memperindah kampungnya. Awal munculnya kampung Pelangi pertama di Indonesia yaitu Kampung Code di Yogyakarta, namun kampung Pelangi di Indonesia mulai populer sejak kemunculan Kampung Jodipan di Malang pada tahun 2016. Sejak saat itu mulai bermunculan 
kampung pelangi di Bandung, Surabaya, Jakarta, Semarang, Balikpapan, dan berbagai kota lainnya. Dengan hadirnya kampung pelangi di berbagai tempat tanpa memiliki latar belakang yang jelas, seakan membuat istilah kampung pelangi sebagai tempat wisata tersebut hanya sebagai label.

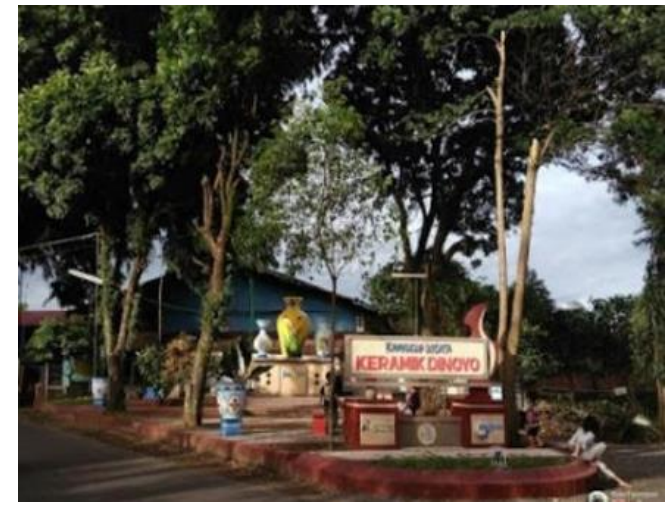

Gambar 1 Kampung Wisata Keramik Dinoyo, Malang

Sumber: kimkanuruhan.com

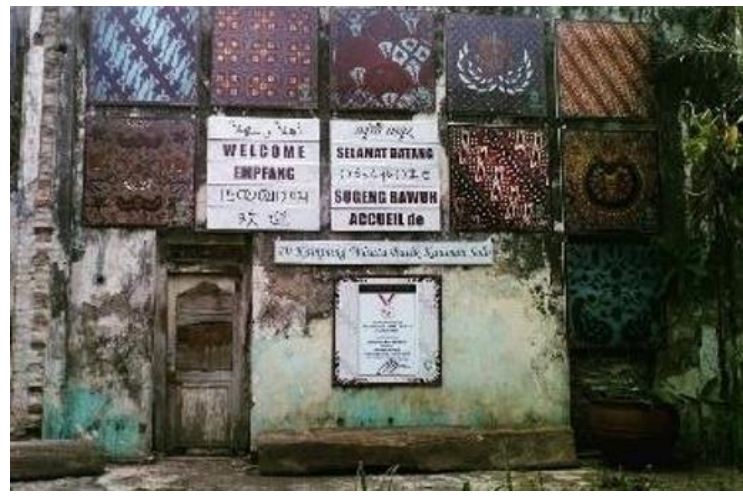

Gambar 2 Kampung Batik kauman, Solo Sumber: phinemo.com

Fenomena kampung wisata ini selain terjadi di indonesia, juga terjadi di negara lainnya seperti Seperti kampung Chefchaouen di Maroko, seluruh elemen pada kampung tersebut dilapisi warna biru. Hal tersebut dilakukan bukan karena tanpa alasan, melainkan merupakan sebuah tradisi penduduk setempat dengan mewarnai semua barang dengan warna biru untuk menyamakan dengan warna langit agar mengingatkan mereka pada Tuhan. Sebagai tempat wisata, kampung ini menawarkan keindahan alam pegunungan setempat dan tata ruang kampung yang unik. Selain itu juga terdapat fasilitas penginapan bagi para wisatawan. Lain halnya dengan kampung wisata Gamcheon Culture Village di Korea yang merupakan kampung warna-warni, namun dilakukan dalam rangka mengatasi wilayah kumuh agar terlihat lebih indah. Gamcheon Culture Village juga dilengkapi sarana dan prasarana memadai seperti penginapan, tempat makan, toilet dan sebagainya.

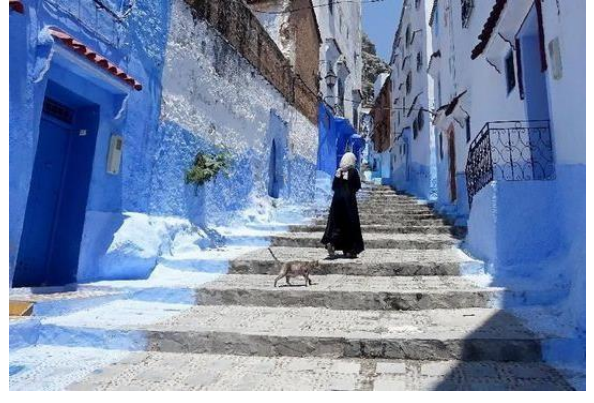

Gambar 3 Chefchaouen, Maroko Sumber: CNN Indonesia

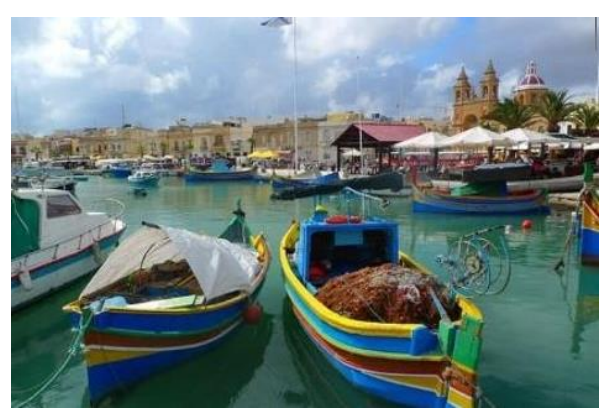

Gambar 4 Marsaxlokk village, Malta Sumber: autoblizz.blogspot.com

Pada dasarnya kampung dan wisata merupakan dua entitas dengan sistem berbeda. Menurut Herbasuki (1984), kampung kota adalah lingkungan perumahan tradisional yang spesifik di Indonesia, ditandai dengan ciri kehidupan yang terjalin dalam ikatan kekeluargaan yang erat. Sedangkan wisata menurut UU No. 10 Tahun 2009 tentang Kepariwisataan Bab 1 Pasal 1 menyebutkan bahwa wisata merupakan kegiatan perjalanan yang dilakukan oleh 
seseorang atau sekelompok orang dengan mengunjungi tempat tertentu untuk tujuan rekreasi, pengembangan pribadi, atau mempelajari keunikan daya tarik wisata yang dikunjungi dalam jangka waktu sementara. Kampung kota sebagai tempat bermukim merupakan suatu kegiatan berkepanjangan, sedangkan wisata merupakan kegiatan temporer. Dengan dijadikannya suatu kampung kota sebagai tempat wisata, kampung tersebut memiliki makna lebih dari sekedar tempat bermukim masyarakat di suatu kota. Ruang pada kampung tersebut tidak lagi menjadi milik bagi warga setempat karena kini terdapat kebutuhan untuk berbagi ruang dengan wisatawan yang merupakan pendatang dari luar, sehingga perlu dilengkapi dengan berbagai fasilitas, yang memadai.

Berdasarkan pemaparan tersebut, penulis tertarik untuk meneliti bagaimana setting elemen fisik dapat membangun karakter kampung wisata sehingga dapat diketahui apa faktor yang membuktikan sebuah kampung layak sebagai tempat wisata. Melalui penelitian ini diharapkan dapat menjelaskan adanya peran setting elemen fisik kampung wisata sehingga dapat terlihat perbedaan wisata yang ditawarkan pada kedua objek studi. Setelah itu dilanjutkan dengan melihat bagaimana konsep wisata pada kampung dapat terpenuhi, dibuktikan dengan adanya elemen fisik. Sehingga pertanyaan penelitian akan dibahas pada penelitian kali ini adalah: Bagaimana peran setting elemen fisik (arsitektur) yang terjadi pada Kampung Lawas Maspati dan Kampung Pelangi Kenjeran?

Penelitian ini bertujuan untuk menguraikan seberapa jauh kedua objek studi sebagai tempat wisata, hal tersebut diketahui dengan meninjau setting elemen fisik pada kedua objek studi berdasarkan kriteria wisata yang ada sehingga dapat memberi pembuktian apakah kedua objek studi tersebut berperan selayaknya sebagai objek wisata, atau hanya merupakan sebuah label dalam memberikan istilah wisata.

Seiring banyak bermunculannya kampung yang berinovasi di berbagai kota di Indonesia, penelitian ini diharapkan dapat memberi kontribusi ilmiah mengenai kampung wisata mengenai hal apa saja yang perlu dimiliki kampung wisata agar menjadi objek wisata yang layak. Adanya penelitian ini dapat menjadi kajian akademis untuk meningkatkan mutu dari kampung wisata itu sendiri.

Penelitian ini diharapkan dapat menjadi bahan kajian bagi para praktisi dalam melakukan inovasi khususnya di bidang kampung wisata sehingga dapat dijadikan sebagai pertimbangan dalam menciptakan kampung-kampung wisata yang akan datang.

Penelitian ini berfokus pada kriteria objek wisata. Kampung wisata yang digunakan sebagai objek studi akan diidentifikasi berdasarkan kriteria yang perlu dimiliki objek wisata.

\section{KAJIAN TEORI}

Rapoport (1980) menjelaskan setting sebagai tata letak dari suatu interaksi manusia dan lingkungannya untuk mengetahui tempat dan situasi dengan apa mereka berhubungan. Adanya situasi yang berbeda akan menyebabkan tata letak yang berbeda pula. Adapun setting terdiri atas elemen fixed, semi fixed, dan non fixed.

Elemen fixed merupakan lemen tetap yang perubahannya jarang. Secara spasial elemen ini dapat diorganisasikan ke dalam ukuran, lokasi, urutan, dan susunan. Dalam beberap kasus dapat dilengkapi oleh elemen lain seperti bangunan dan perlengkapanjalan yang melekat. Elemen semi fixed merupakan elemen yang agak tetap tetapi berkisar dari susunan dan tipe elemen seperti jaan, tanda iklan, etalasae took dan elemen urban lainnya yang perubahannya cukup cepat seperti adanya pedagang kaki lima (PKL), parkir, dan penanda. Elemen non fixed ini berhubungan dengan tingkahlaku atau perilaku yang ditunjukan manusia itu sendiri yang sifatnya tidak tetap seperti posisi tubuh, postur tubuh, gerak anggota tubuh. Elemen non fixed 
terdiri atas pejalan kaki, pergerakan kendaraan bermotor dan tidak.

Jon Lang (1997) menyebutkan bahwa layout yang mampu beradaptasi dapat menyediakan pola perilaku yang berbeda pada waktu yang berbeda tanpa membutuhkan perubahan setting fisiknya. Sedangkan layout yang fleksibel adalah layout yang dapat berubah dengan cepat untuk mengakomodasi kebutuhan yang berbeda-beda. Dalam penelitian ini hal tersebut sangat berkaitan dengan kampung wisata, karena dengan adanya aktivitas wisata pada sebuah kampung, diperlukan setting yang memadai untuk aktivitas yang diwadahinya.

Sarwono (1992) menambahkan bahwa lingkungan memiliki estetika yang dipengaruhi oleh kesukaan (preferensi) terhadap lingkungan yang berbeda-beda, prefrensi tersebut ditentukan oleh beberapa hal, antara lain keteraturan, tekstur, keakraban lingkungan, keluasan ruang pandang, dan kemajemukan rangsang.

Ching, Francis D.K. (1979) menyebutkan bahwa dalam perbendaharaan arsitektural setiap elemen awalnya merupakan sebuah elemen konseptual, lalu sebagai elemen visual. Elemenelemen konseptual seperti titik, garis, bidang, volume awalnya tidak dapat dilihat kecuali oleh mata pikiran, meskipun tidak ada secara aktual namun kehadirannya dapat dirasakan.

Adanya konteks kampung yang dimaksud dalam penelitian kampung wisata ini tidak lain adalah kampung kota yang menjadi tempat terjadinya aktivitas wisata itu sendiri, sehingga pada bab ini akan dimulai pengertian objek wisata secara umum, kemudian dilanjutkan dengan penjelasan kampung kota, dan kampung wisata yang akan menjadi objek penelitian secara lebih lanjut. Adanya kegiatan wisata pada kampung wisata tidak terlepas sebagai suatu bentuk aktivitas baru pada suatu kampung, sehingga aktivitas yang berkaitan dengan wisata akan menjadi hal yang penting dalam penelitian dan akan dibahas pada bab teori ini.

Dalam ranah wisata, Yoeti (1985) menjelaskan agar suatu objek wisata menarik untuk dikunjungi wisatawan, perlu memiliki daya tarik wisata. yaitu segala sesuatu yang menjadi daya tarik bagi orang (wisatawan) untuk mengunjungi suatu daerah tertentu, dan adapun agar sebuah objek dapat disebut sebagai objek wisata, maka objek tersebut perlu memiliki tiga hal, yaitu something to see, something to do, dan something to buy.

Something to see menjelaskan bahwa agar suatu tempat mendapat perhatian maka harus terdapat elemen yang manarik untuk dilihat, dalam pengertian terdapat elemen yang membedakan tempat tersebut dengan tempat lainnya baik yang bersifat tangible (pemandangan, bangunan, ornamen) maupun intangible (seni pertunjukan, ritual, perayaan). Bila dilihat dari sudut pandang arsitektur, something to see berkaitan dengan sebuah place, di mana place terbentuk dari adanya ruang sebagai elemen fisik dan aktivitas yang terdapat di dalamnya.

Something to do menjelaskan apa saja aktivitas yang dapat dilakukan pengunjung/wisatawan selama berwisata di suatu tempat. Bila dilihat dari sudut pandang arsitektur, adanya aktivitas tidak terlepas dari tempat yang mewadahinya. Gehl (Life Between Buildings, 2011) menyebutkan bahwa aktivitas yang dilakukan seseorang atau sekelompok orang yang berada pada ruang yang sama merupakan daya tarik tersendiri bagi orang lain karena orang memiliki kecenderungan untuk berada di dekat orang lain. Sebagai contoh, ketika terdapat sebuah pekerjaan konstruksi di pinggir jalan maka orang yang lewat memiliki kecenderungan untuk berhenti dan atau sekedar melihat (walau hanya sejenak) orang yang melakukan pekerjaan tersebut. Pekerjaan yang dilakukan pekerja konstruksi tersebut merupakan sebuah daya tarik, bukan bangunan yang sedang dikerjakannya. Dalam arsitektur, hubungan antara aktivitas dengan ruang yang mewadahinya tersebut diartikan sebagai sebuah tempat (Trancik, 1986).

Something to buy diartikan sebagai fasilitas wisata di mana pengunjungnya dapat berbelanja, yang pada umumnya berupa hasil / ciri khas daerah tersebut. Dengan adanya benda 
sebagai ciri khas objek wisata yang dapat dibeli wisatawan, hal ini meningkatkan makna baik bagi wisatawan maupun tempat wisata itu sendiri. Adanya aspek something to buy menuntut suatu interaksi antar manusia, dalam konteks wisata yaitu wisatawan dan pedagang. Interaksi tersebut lebih lanjut diartikan sebagai sebuah aktivitas (jual-beli) yang terjadi pada suatu tempat.

Penjelasan mengenai kampung kota, terutama kampung kota di Indonesia telah banyak dirumuskan melalui berbagai sudut pandang, menyesuaikan dengan situasi, kondisi dan lokasi keberadaan kampung tersebut. Apabila dilihat dari ciri khas dan budaya masyarakatnya, Ever (1985) mengartikan sebuah kampung kota sebagai bagian dari kota namun masih mempertahankan ciri-ciri desa. Jika dilihat dari sudut pandang D. Sujarto (1980) menyatakan bahwa, "Kampung kota merupakan suatu lingkungan tempat tinggal yang berkepadatan tinggi, terdiri atas kumpulan rumah dengan kontruksi bengunan temporer atau semi permanen, tanpa halaman cukup, serta prasarana fisik lingkungan yang kurang memadai. Lingkungan tempat tinggal ini umumnya dikelilingi oleh deretan-deretan bangunan permanen". Di sisi lain Turner (1972) mecoba mendeskripsikan kondisi dalam lingkungan kampung kota itu sendiri melalui pernyataannya, "Kampung kota merupakan kawasan permukiman kumuh dengan penyediaan sarana umum yang sangat buruk atau tidak ada sama sekali." Melalui berbagai pandangan tersebut kampung kota digambarkan sebagai suatu tempat yang memiliki berbagai citra negatif, tertinggal, kumuh, kotor, sehingga fungsi utamanya sebagai tempat untuk bermukim terkesan sebagai tempat yang kurang layak huni.

Adapun pandangan lainnya yang bertolak belakang dengan penjelasan- penjelasan sebelumnya yang mengemukakan kampung kota merupakan bagian dari kota itu sendiri, sehingga perlu dipertahankan. Dalam penelitiannya yang berjudul Mofrofolgi Urban Artefak Kampung Kota, Ikaputra dan Anityas (2020) menyebutkan kampung kota sebagai bentuk permukiman yang tidak terencana (unplanned) merupakan bagian dari sebuah kota yang dalam sejarahnya membentuk atau merupakan bagian dari kota tersebut. Sebagai bagian dari kota, kampung kota itu sendiri memiliki prinsip-prinsip morfologi urban artefact yang terdiri atas jalan (streets), lahan (plots), dan bangunan (buildings).

Adanya kedua pandangan yang saling bertolak belakang tersebut membuat respon yang berbeda-beda dari bebagai pihak. Pihak yang melihat kampung kota sebagai tempat kumuh dan tidak layak huni berpendapat kampung kota perlu disingkirkan dan dibuat tempat baru yang lebih layak. Namun pihak yang berpendapat kampung kota sebagai bagian dari kota dan perlu dipertahankan melihat kampung kota sebagai potensi yang dapat dikembangkan karena memiliki beragam nilai (sejarah, budaya, ekonomi) bagi perkembangan kotanya.

Lansing De Vries (2007) menyebutkan bahwa kampung wisata sebgai konsep wisata berkelanjutan (sustainable tourism) Konsep ini diklaim sebagai konsep baru yang mampu mengatasi persoalan pengembangan wisata secara konvensional. Jika dilihat dari akar budaya yang masih mengadopsi kebiasaan masyarakat desa, kampung wisata dapat didefinisikan sebagai suatu integrasi antara daya tarik, akomodasi dan fasilitas pendukung yang disajikan dalam suatu struktur kehidupan masyarakat yang menyatu dengan tata cara dan tradisi yang berlaku (Yoeti 1985). Adapun Menurut Pariwisata Inti Rakyat (PIR) yang dimaksud dengan desa wisata adalah suatu kawasan pedesaan yang menawarkan keseluruhan suasana yang mencerminkan keaslian pedesaan baik dari kehidupan sosial ekonomi, sosial budaya, adat istiadat, keseharian, memiliki arsitektur bangunan dan struktur tata ruang desa yang khas.

Munculnya kekhasan potensi wisata pada kampung kota yang ada di Indonesia terbentuk dari latar belakang kampung yang beragam. Sebut saja seperti Kampung Keramik yang berada di Malang, di mana sebagian besar penduduknya berprofesi sebagai pengrajin keramik seiring dengan dijadikannya Malang sebagai industri keramik sejak 1957. Lain halnya dengan Kampung Pelangi Jodipan yang berada di Malang. Kampung ini pada awalnya 
merupakan kampung kumuh yang hampir digusur pemerintah setempat, namun sejumlah mahasiswa berupaya membenahi kampung tersebut dan mengecat bangunan- bangunan yang ada pada kampung tersebut menjadi warna-warni. Dari kedua contoh tersebut dapat terlihat hal yang membedakan kampung wisata satu dengan lainnya.

\section{METODE PENELITIAN}

Penelitian ini merupakan penelitian kualitatif - deskriptif dengan melakukan observasi seputar komponen yang perlu dimiliki objek wisata di Kampung Lawas Maspati dan Kampung Pelangi Kenjeran. Temuan data di lapangan dipetakan, diidentifikasi dengan teori yang digunakan untuk dianalisis.

Penelitian ini dilakukan di beberapa tempat di Kota Surabaya pada bulan Oktober 2020 - November 2020. Kota Surabaya merupakan salah satu kota yang sukses dalam upaya menata kotanya, salah satunya dengan menjadikan kampung kota menjadi kampung wisata. Kampung wisata yang dijadikan objek penelitian antara lain Kampung Lawas Maspati dan Kampung Pelangi Kenjeran, keduanya berada di Kota Surabaya.

Pengumpulan data dilakukan dengan beberapa cara. Pengumpulan infrmasi yang sesuai dan benar dicapai melalui ketepatan pemilihan responden. Metode pengumpulan data yang terkait pada penelitian ini terdiri dari dua metode yaitu data primer seperti wawancara, observasi, dan dokumentasi. Sedangkan melalui data sekunder yaitu dengan mempelajari penelitian-penelitian sebaelumnya pada objek terkait baik melalui artikel, makalah, berita, maupun dokumentasi yang sudah ada.

Ketika melakukan analisis dalam pengumpulan data, terdapat tahap di mana data diproses dan diedit agar mudah dalam penyajiannya (Darjosanjoto, 2012). Penyajian data dilakukan agar dapat fokus pada visualisasi data di lapangan, dalam bentuk data kawasan kampung berupa peta/gambar, table, diagram-diagram

Tujuan dari analisis data yaitu menjawab pertanyaan-pertanyaan terkait permasalahan penelitian dengan mencari dan mengolah data yang ada secara sistematis, yang diperoleh baik melalui pengumpulan data primer maupun sekunder. Teknik analisis data pada penelitian ini terdiri atas beberapa tahap meliputi reduksi data, penyajian data, komparasi, dan penarikan kesimpulan.

\section{ANALISIS}

Yoeti (1985) meyebutkan, sebuah objek wisata perlu memiliki daya tarik agar dikunjungi wisatawan. Daya Tarik wisata tersebut terdiri atas tiga hal yaitu something to see, something to do, dan something to buy. Dalam penelitian ini ketiga kriteria tersebut akan ditinjau dari sudut pandang arsitektur, bagaimana arsitektur sebagai objek fisik dapat berperan dalam mengakomodir ketiga kriteria tersebut, untuk membuktikan adanya wisata pada kedua objek studi. Selanjutnya dari kedua objek studi akan dibandingkan dan ditinjau sejauh apa kesiapannya sebagai kampung wisata. 


\subsection{KAMPUNG LAWAS MASPATI}

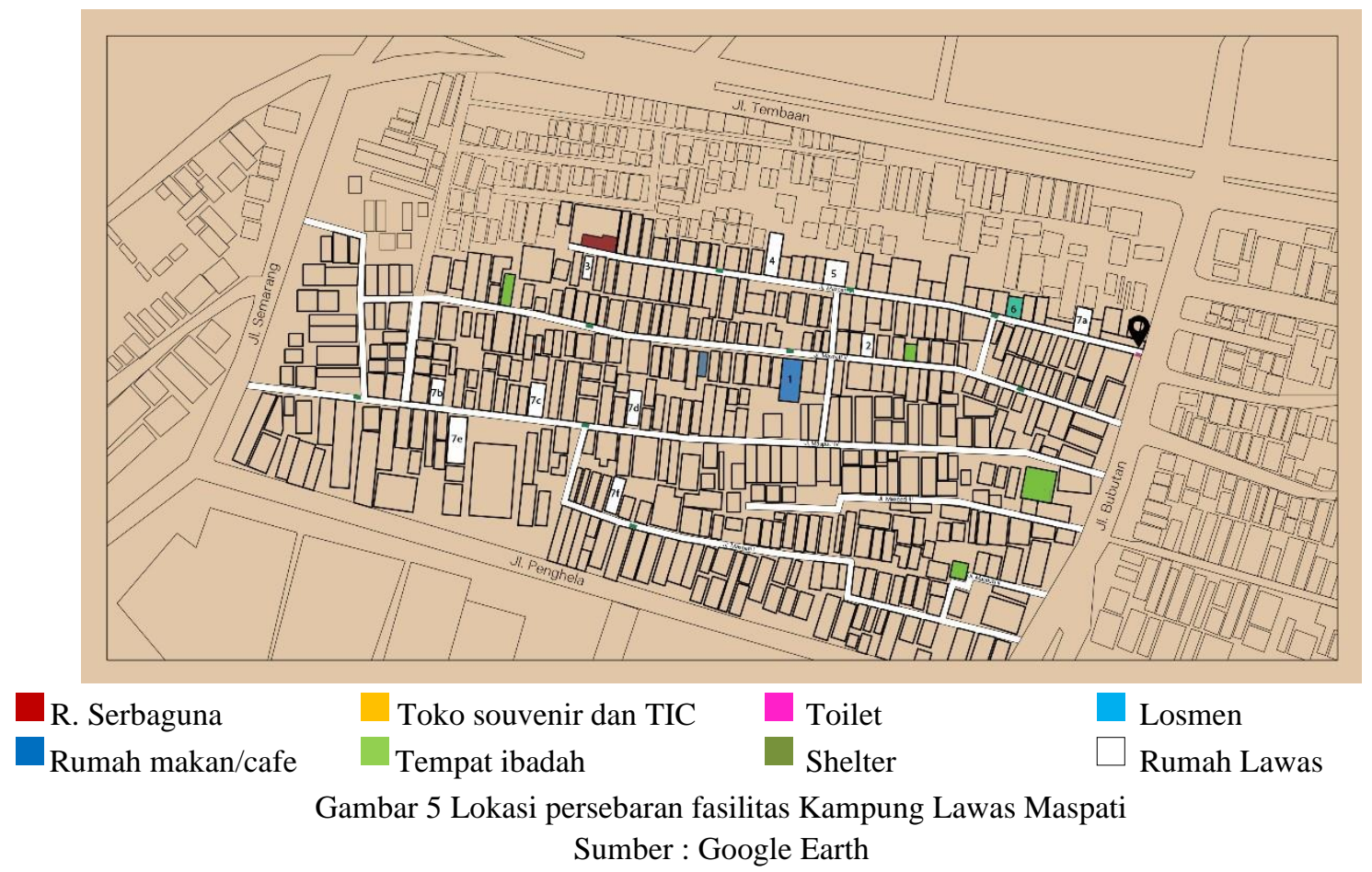

Sebagai tempat wisata sejarah, kampung lawas maspati memiliki objek- objek yang menarik untuk dilihat (something to see), seperti bangunan lawas yang memiliki sejarah tertentu maupun aktivitas warganya itu sendiri. Koridor jalan kampung juga ditata agar menjadi objek yang menarik untuk dilihat, dengan adanya mural pada bidang jalan, penataan pot tanaman di sepanjang kiri dan kanan jalan, dan elemen lainnya. Selain itu terdapat beberapa hal yang dapat dilakukan wisatawan (something to do) Ketika berkunjung ke Kampung Lawas Maspati, seperti tur keliling kampung, menyaksikan pertunjukan, bermain Bersama warga setempat, kuliner dan membeli beberapa produk hasil olahan warga kampung setempat yang juga sebagai bentuk sesuatu yang dapat dibeli wisatawan (something to buy).

\subsubsection{PENANDA}

Terdapatnya something to see, something to do, dan something to buy pada Kampung Lawas Maspati didukung oleh adanya elemen fisik yang memadai. Elemen fisik tersebut antara lain seperti penanda yang terdapat di beberapa tempat, seperti gapura pada Jl. Maspati VI dan petunjuk jalan dan lokasi objek yang tersebar di beberapa tempat. Hal ini membantu wisatawan untuk memberi petunjuk dan orientasi kepada wisatawan agar Kampung Lawas Maspati lebih mudah dikenali sebagai kampung wisata. 


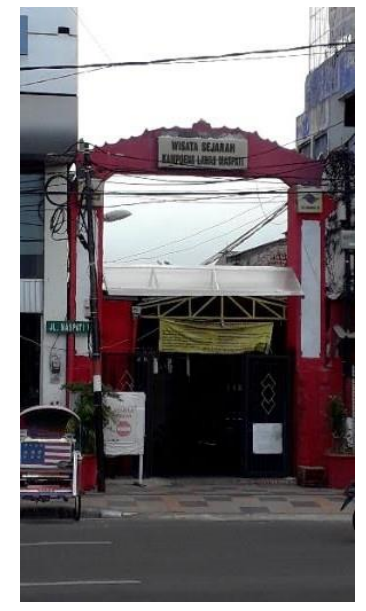

Gambar 6 Penanda pada gerbang Jl. Maspati VI Survey: 14 Oktober 2020

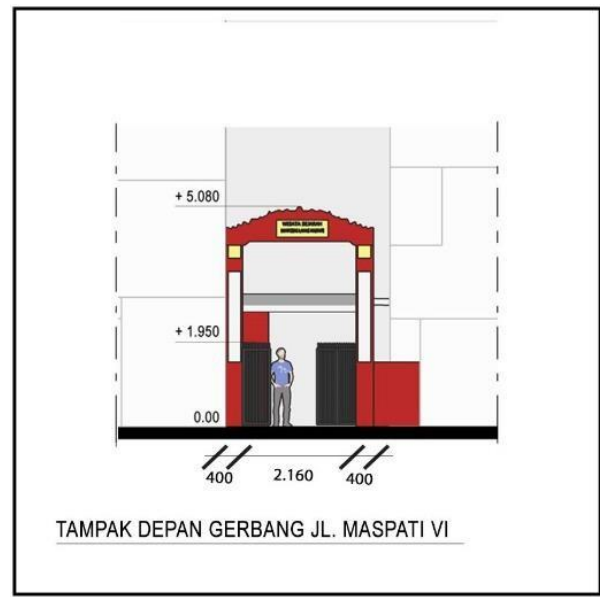

Gambar 7 Gerbang Jl. Maspati VI Sumber: Dokumentasi penulis

\subsubsection{SHELTER}

Salah satu aktivitas wisata yang ada pada Kampung Lawas Maspati yaitu tur keliling kampung. Berdasarkan keterangan narasumber, aktivitas ini berlangsung selama dua hingga tiga jam. Maka dari itu agar wisatawan tidak kelelahan saat menjelajahi area kampung, disediakan shelter dengan tempat duduk yang tersebar di beberapa tempat di setiap jalan Kampung Lawas Maspati untuk beristirahat dan berteduh. Shelter yang terdapat pada Kampung Lawas Maspati terdapat beberapa tipe dan ukuran. Ukuran paling kecil merupakan yang paling banyak tersebar di koridor jalan adalah shelter yang memiliki kapasitas dua orang. Shelter ini merupakan elemen semi fixed, karena bersifat movable (dapat dipindahkan). Sehingga ketika ada aktivitas lain yang membutuhkan ruang tertentu, shelter ini dapat digunakan sebagai blokade jalan untuk membentuk ruang.

Terdapat shelter lain yang berukuran lebih besar, dapat memuat tiga orang dewasa dan terbuat dari bambu, yang terletak di Jl. Maspati IV. Namun shelter ini cenderung sebagai elemen tambahan untuk menata tanaman. Shelter ini tidak dinaungi atap, namun rangka atapnya digunakan sebagai tempat untuk meletakkan tanaman pada pot gantung. Shelter ini jarang digunakan oleh wisatawan karena letaknya yang kurang setrategis sehingga jarang terjangkau, tepatnya di ujung Jl. Maspati IV.

Jenis shelter yang bersifat semi fixed yang lainnya yaitu terdapat di Jl. Maspati V. Kampung Lawas Maspati memiliki rumah pengelolaan sampah, sampah-sampah tersebut didaur ulang untuk dijadikan kerajinan yang memiliki nilai fungsi kembali seperti baju, tas, gaun, dan sebagainya. Saat wisata berlangsung, barang-barang hasil daur ulang tersebut dipamerkan kepada wisatawan maka dari itu disediakan tempat khusus untuk kegiatan pameran tersebut. 


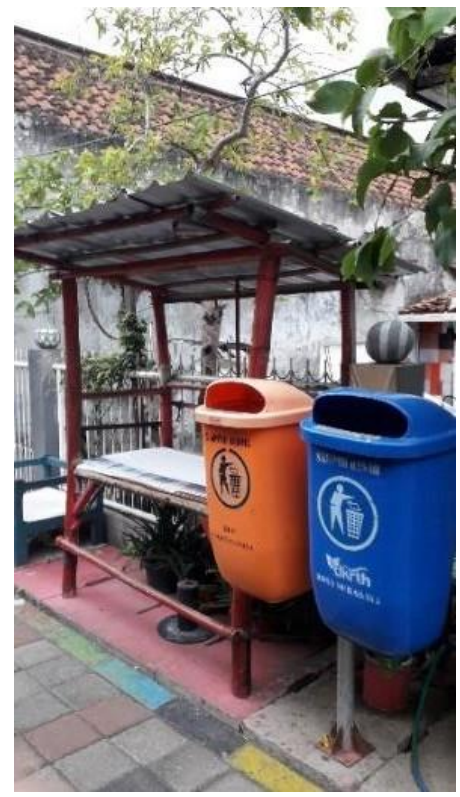

Gambar 8 Shelter di Kampung Lawas Maspati Survey: 14 Oktober 2020

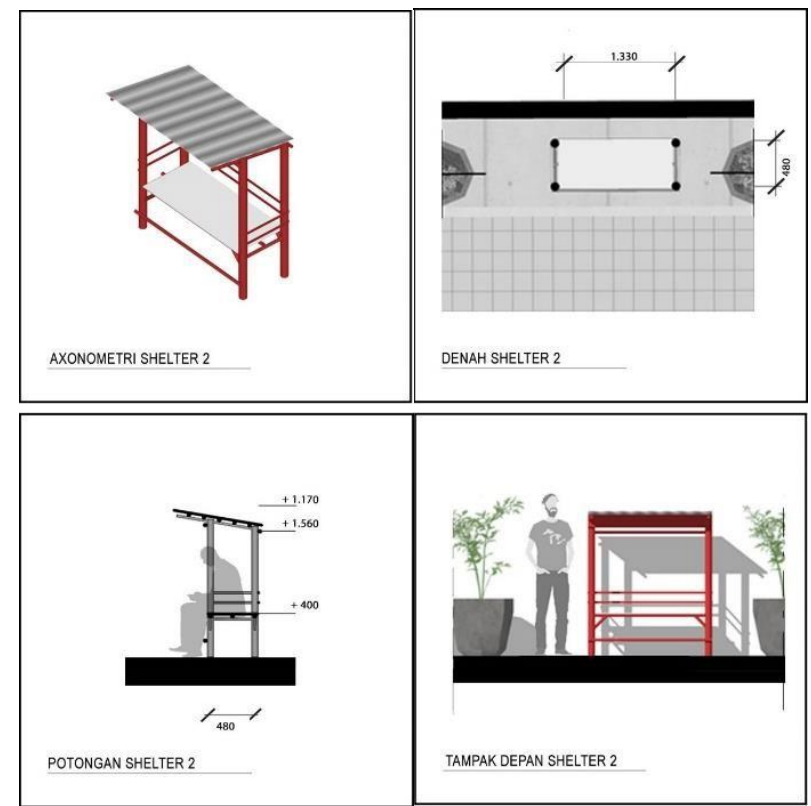

Gambar 9 Gambar Terukur Shelter Sumber: Dokumentasi penulis

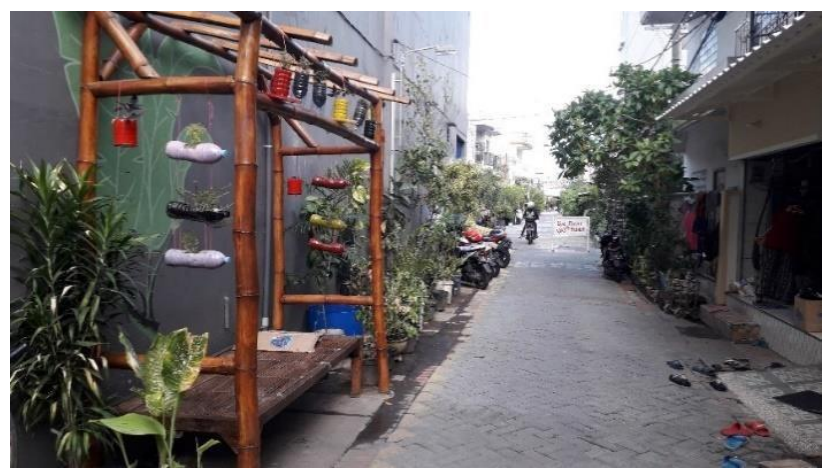

Gambar 10 Shelter di Kampung Lawas Maspati Survey: 14 Oktober 2020
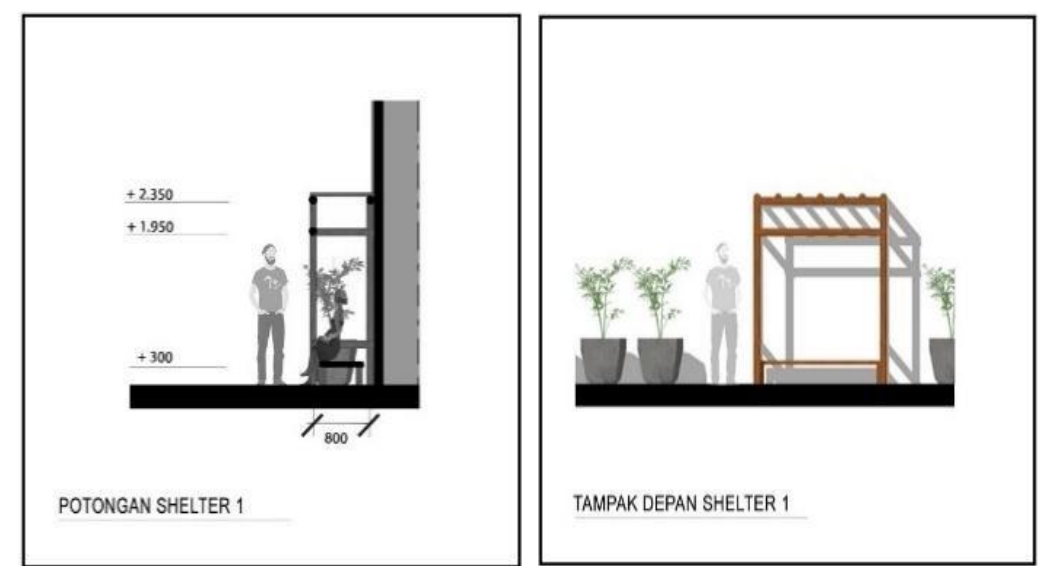

Gambar 11 Gambar Terukur Shelter

Sumber: Dokumentasi penulis 


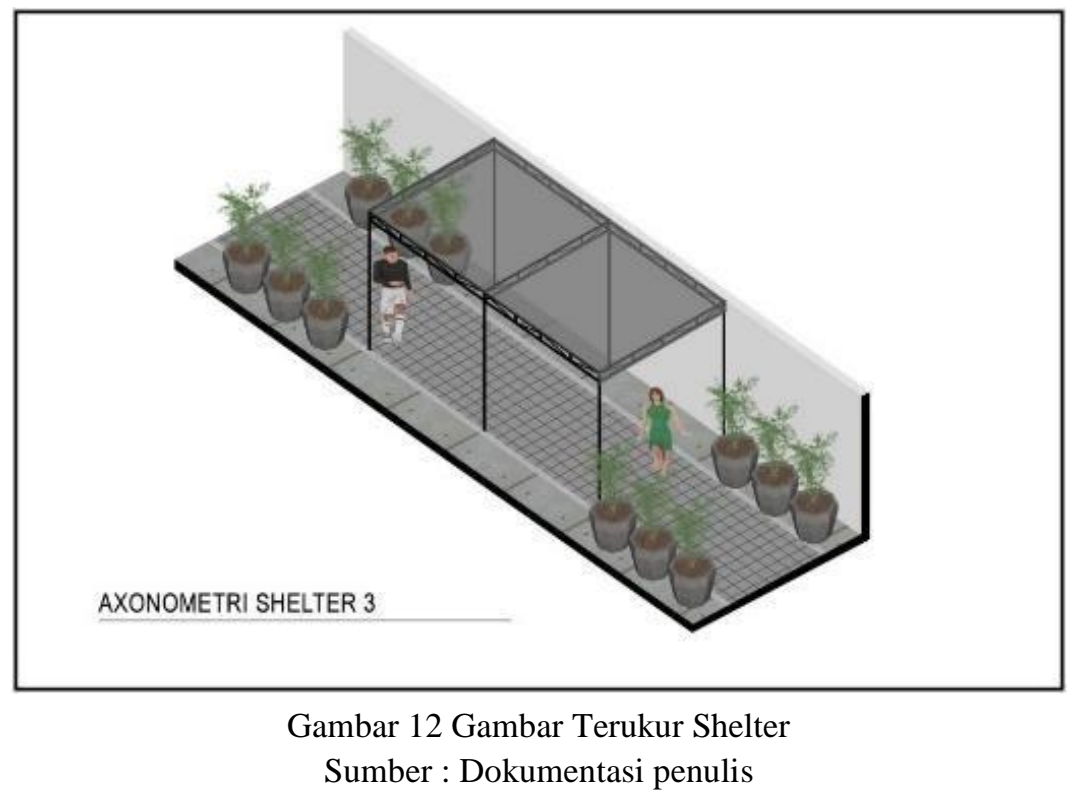

\subsubsection{TEMPAT MAKAN}

Sebagian fasilitas tempat makan pada Kampung Lawas Maspati memanfaatkan bangunan lama sebagai tempatnya. Terdapat beberapa fasilitas akomodasi untuk wisatawan, diantaranya rumah makan, café, dan penginapan. Jenis bangunan lawas pada kampung ini menjadi potensi tersendiri bagi fasilitas akomodasi pada Kampung Lawas Maspati, karena dapat digunakan sebagai konsep ruangan yang dipakai.

Seperti Omah Tua 1907 Café \& Library, yang berada di Jl. Maspati V. Sebelumnya tempat ini berfungsi sebagai rumah tinggal, pernah menjadi markas tentara dan kini termasuk sebagai salah satu bangunan cagar budaya Kota Surabaya. Untuk mempertahankan konsep lawas pada café ini, Tidak terdapat banyak perubahan pada elemen asli bangunan ini. Namun untuk memenuhi fungsi barunya sebagai café, diberi tambahan elemen fisik seperti furnitur, penanda, dan dilakukan perubahan fungsi dan layout pada ruang dalam yang sesuai dengan konsep ruang aslinya baik dari penggunaan material dan warnanya.

Seluruh ruangan pada bangunan ini dijadikan sebagai area café termasuk fungsi ruang pendukungnya seperti toilet, r. penyimpanan, toilet, dan pantry. Bagian depan bangunan merupakan area yang paling banyak mengalami penambahan elemen lain seperti layout dan furniture custom, dan penanda café. 


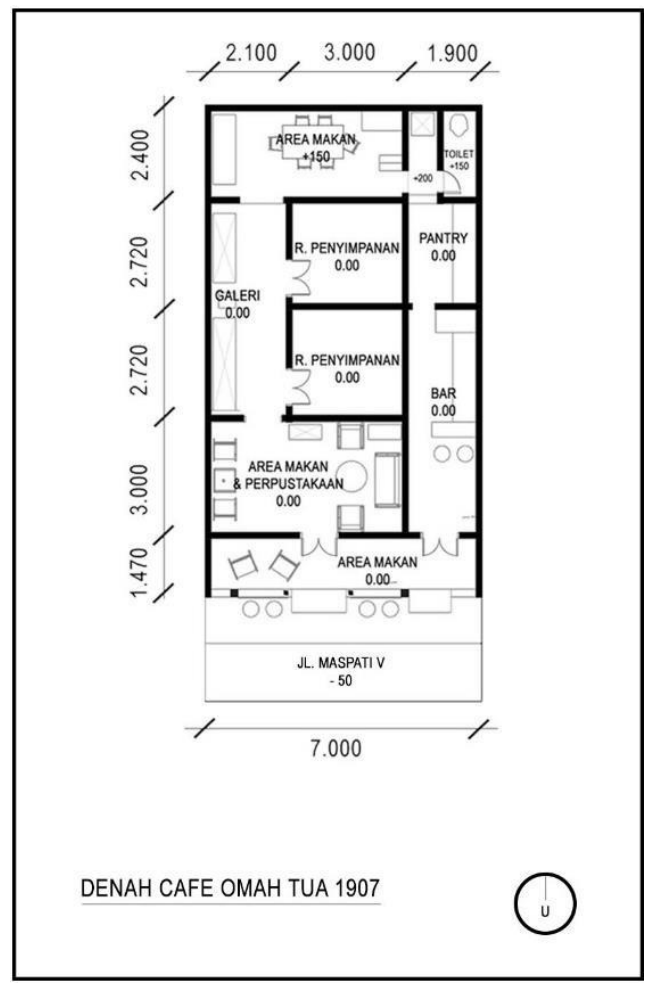

Gambar 13 Denah Omah Tua Café \& Library

Sumber: Dokumentasi penulis

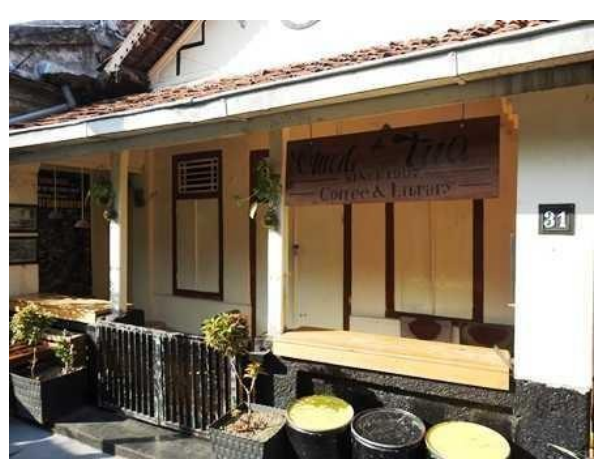

Gambar 14 Omah Tua Café \& Library Sumber: Dokumentasi penulis

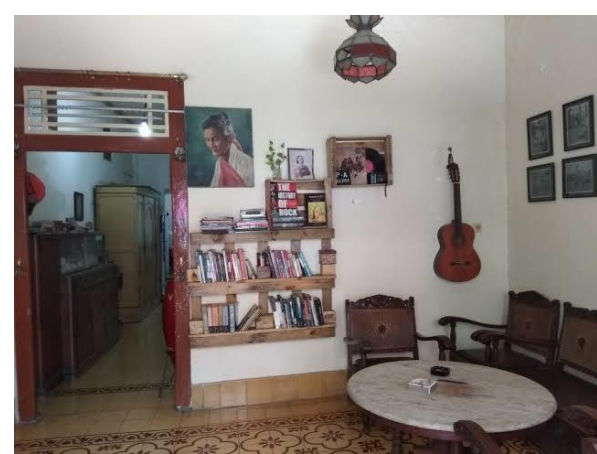

Gambar 15 Omah Tua Café \& Library Survey: 14 Oktober 2020

Fasilitas akomodasi lain yang terdapat di Kampung Lawas Maspati yaitu rumah makan De Gudeg, yang merupakan rumah makan gudeg, berada di Jl. Maspati V. Awalnya tempat ini merupakan rumah tinggal biasa yang dijadikan rumah makan, namun untuk membangun suasana "lawas" sesuai tema pada kampung ini diberi tambahan elemen fisik dengan material oraganik (bambu, kayu) berupa dinding partisi, dan layout ruang dengan menambahkan bukaan yang membatasi area penjual dan pembeli, dan area makan. Tidak terdapat banyak perubahan pada bangunan ini, area yang dijadikan tempat makan dan dimasuki wisatawan sebatas berada di area teras rumah dan Jl. Masapati V. 


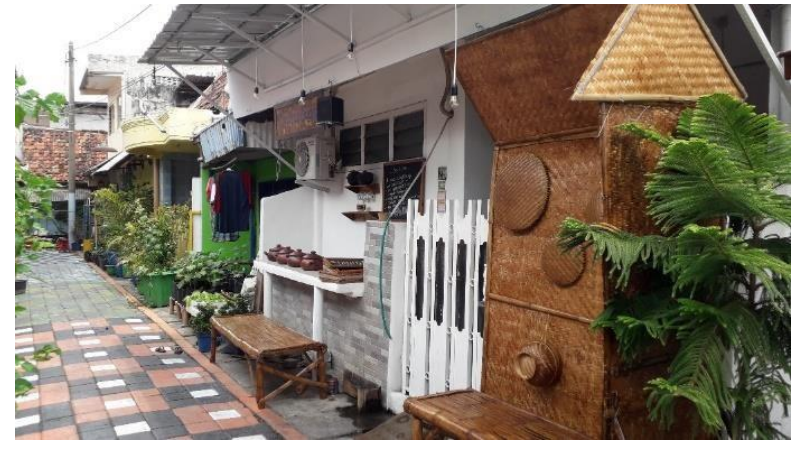

Gambar 16 Rumah Makan De Gudeg Survey: 14 Oktober 2020

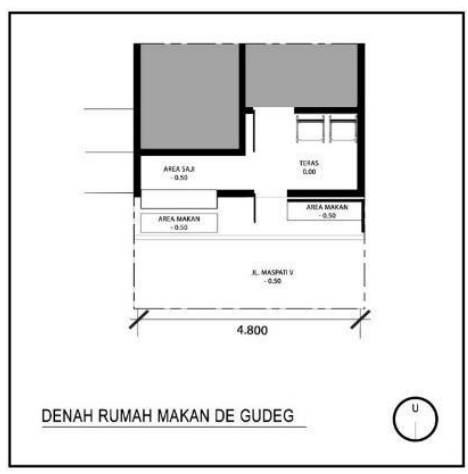

Gambar 17 Denah Rumah Makan De Gudeg Sumber : Dokumentasi penulis

\subsubsection{AREA BERMAIN}

Permainan tradisional menjadi salah satu daya Tarik yang ditawarkan Kampung Lawas Maspati. Namun karena keterbatasan lahan, tempat bermain permainan tradisional diselenggarakan di beberapa titik di koridor Jl. Maspati VI dengan memanfaatkan sejumlah elemen semi fixed seperti pot tanaman dan penanda visual berupa gambar pada bidang jalan. Elemen fixed yang berperan dalam membentuk ruang pada tempat ini antara lain paving blok sebagai pembatas area pemain dan penonton.

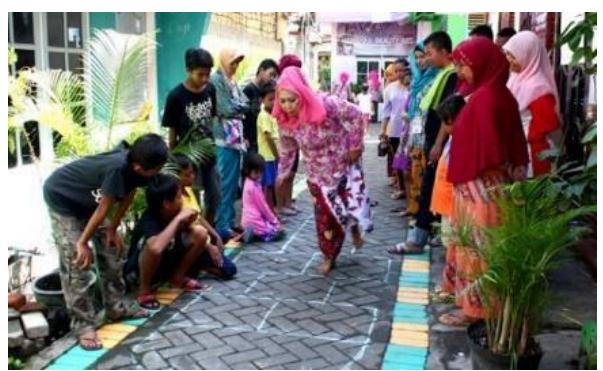

Gambar 18 Aktivitas Bermain Sumber : Swaraguna.com

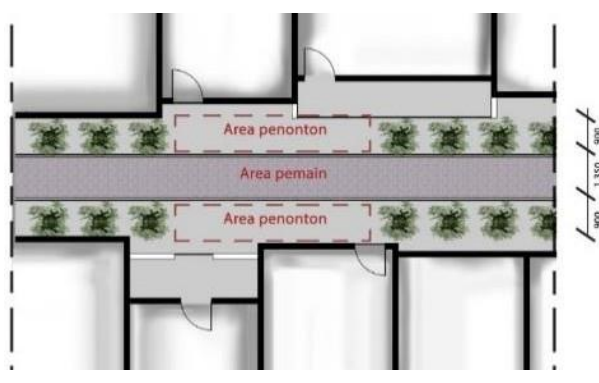

Gambar 19 Ilustrasi Area Bermain di Jl. Maspati VI

Sumber : Dokumentasi Penulis

\subsubsection{TOURIST INFORMATION CENTER DAN TOKO SOUVENIR}

Kampung Lawas Maspati menyediakan benda-benda yang dapat dibeli wisatawan ketika berkunjung seperti souvenir dan makanan khas. Untuk mendukung tersebut, Kampung Lawas Maspati menyediakan fasilitas berupa toko souvenir yang sekaligus berfungsi sebagai tourist information centre (TIC) yang terletak di Jl. Maspati VI.

Toko Souvenir Kampung Lawas Maspati memiliki dimensi yang kurang memadai untuk memenuhi aktivitas dan isi barang yang dikelolanya. Hal tersebut membuat area display pada toko ini mengambil alih sebagian ruang jalan Jl. Maspati VI, hal tersebut berakibat menyempitnya ruang gerak Jl. Maspati VI sebagai jalur sirkulasi baik wisatawan maupun warga kampung. 


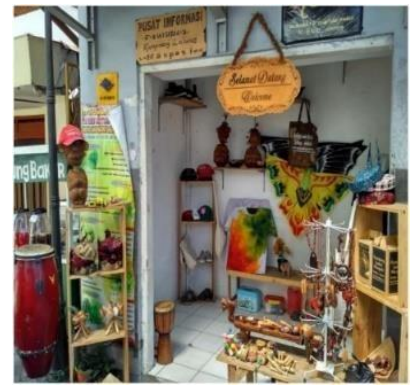

Gambar 20 Toko Souvenir Survey: Docplayer.info

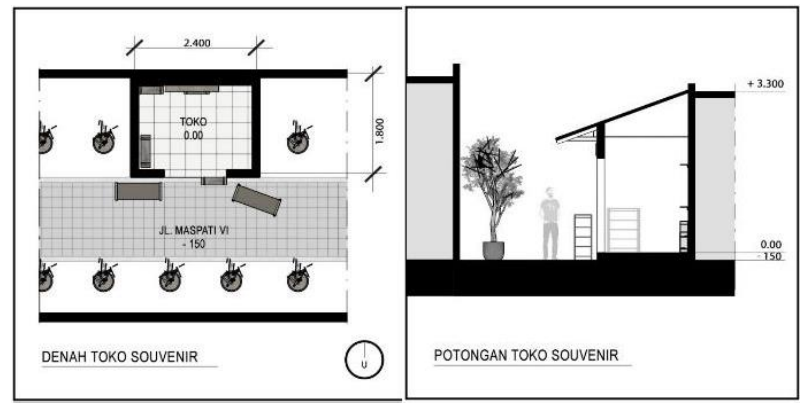

Gambar 21 Gambar Terukur Toko Souvenir Survey: Dokumentasi Penulis

\subsubsection{TOILET}

Salah satu kebutuhan mendasar di berbagai tempat adalah tersedianya toilet. Kampung Lawas Maspati menyediakan fasilitas (khusus) toilet umum yang terdapat pada gerbang masuk Jl. Maspati VI. Namun jika ditinjau dari lokasi, tersedianya toilet ini kurang strategis dan terkesan memaksa karena pada pintu masuk utama lebih baik diisi dengan hal yang dapat membuat kesan mengundang. Di sisi lain, toilet yang terdapat pada masjid dan beberapa rumah warga juga dapat digunakan oleh wisatawan yang berkunjung. Adanya fasilitas khusus toilet terkesan hanya sebagai formalitas untuk memenuhi kebutuhan kampung Lawas Maspati sebagai kampung wisata.

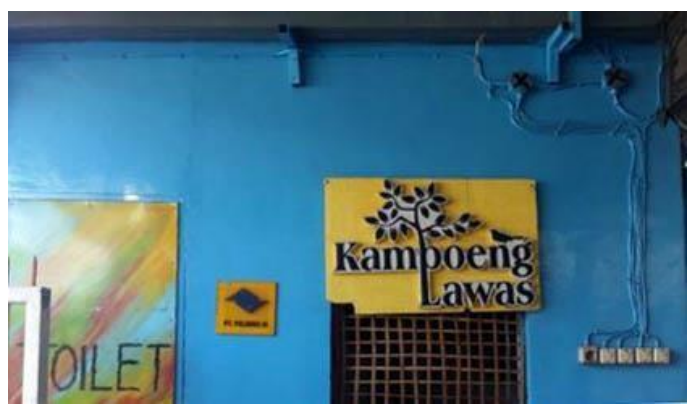

Gambar 22 Toilet Kampung Lawas Maspati Sumber: docplayer.info

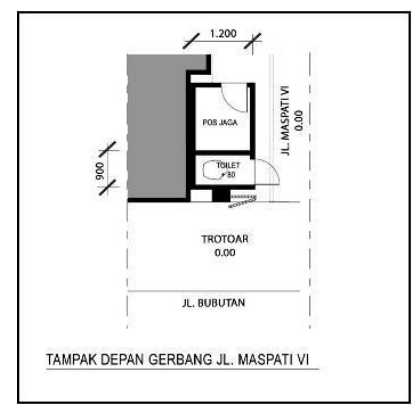

Gambar 23 Denah toilet Kampung Lawas Maspati Sumber : Dokumentasi penulis

\subsubsection{R. SERBA GUNA}

Pertunjukan seni tari dan musik merupakan salah satu daya tarik utama yang diselenggarakan di Kampung Lawas Maspati, sehingga kebutuhan akan ruang pertunjukan menjadi hal yang mutlak. Adapun selain berfungsi sebagai tempat pertunjukan, tempat ini juga dapat dimanfaatkan warga sebagai tempat rapat RT / RT, pemberdayaan dan pelatihan, perkumpulan PKK, dan lainnya sehingga adanya ruang serba guna ini sangat dibutuhkan.

Ruang serba guna ini terletak di ujung Jl. Maspati VI. Karenaadanya keterbatasan lahan, maka untuk menggunakan ruang ini perlu memperluas area hingga ke koridor jalan. Untuk menandai area koridor jalan terpakai, pintu ruang serba guna ini juga berfungsi sebagai atap yang menaungi sebagian koridor jalan. Untunk mengakomodir kebutuhan khusus seperti pertunjukan seni dan tari, elemen fisik lain yang bersifat semi fixed pada koridor jalan seperti pot tanaman dan shelter dimanfaatkan sebagai pembatas ruang, antara area penonton dan performer, maupun area performer dengan backstage.

Ketika sedang diselenggarakan seni pertunjukan, area r. serba guna memiliki orientasi 
kea rah Jl. Maspati VI. Ruang dalam digunakan sebagai area penonton, koridor jalan sebagai area performer, dan ruang di belakang pot tanaman digunakan sebagai area backstage dan sound system, terlihat bahwa masing-masing ruang memiliki perannya masing-masing untuk mewadahi aktivitas di dalamnya. Akses menuju ujung Jl. Maspati VI yang merupakan jalan buntu ditutup dengan shelter tipe yang paling kecil sehingga dapat digunakan sebagai kursi penonton dan menghilangkan kesan ruang mati pada jalan buntu.

Meskipun di Kampung Lawas Maspati memiliki tempat terbatas namun hal tersebut tidak menghalangi upaya untuk membentuk tempat yang layak untuk mewadahi aktivitas yang diselenggarakan. Namun hal ini tetap belum dapat memenuhi faktor kenyamanan secara umum, terutama ketika r. serba guna ini digunakan sebagai tempat pertunjukan. Faktor kenyamanan yang paling dapat dilihat dan dirasakan adalah lokasinya yang bersebelahan dengan area makam Mbah Suruh, di mana makam selayaknya menjadi tempat yang sakral dan jauh dari kebisingan.

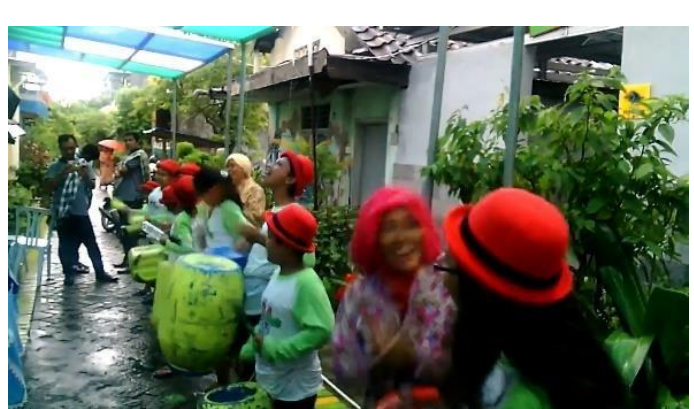

Gambar 24 Pertunjukan music di r. seba guna Sumber: Youtube

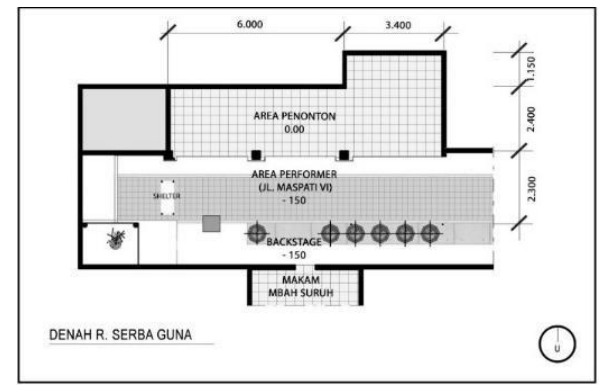

Gambar 25 Denah r. seba guna Sumber : Dokumentasi penulis

\subsubsection{MAKAM MBAH SURUH}

Makam Mbah Suruh yang terletak di Jl. Maspati VI, berseberangan dengan ruang serba guna. Mbah Suruh merupakan salah satu tokoh pelopor berdirinya Kampung Lawas Maspati. Karena merupakan tokoh penting, masyarakat di Kampung Lawas Maspati rutin mengadakan kegiatan penghormatan di makam ini beberapa bulan sekali. Dalam kegiatan wisata, wisatawan yang datang pun turut diperkenalkan ke makam ini baik untuk menceritakan asal-usulnya maupun sekedar ziarah dan berdoa.

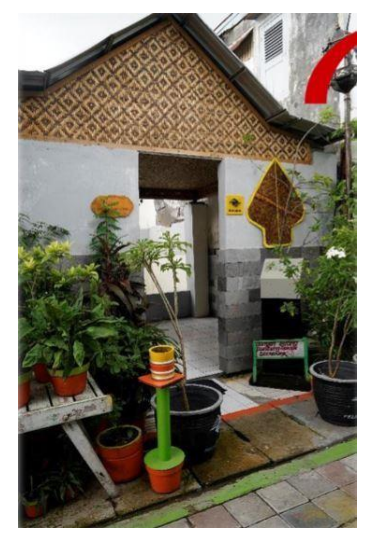

Gambar 26 Shelter Makam Mbah Suruh

Survey: 14 Oktober 2020 


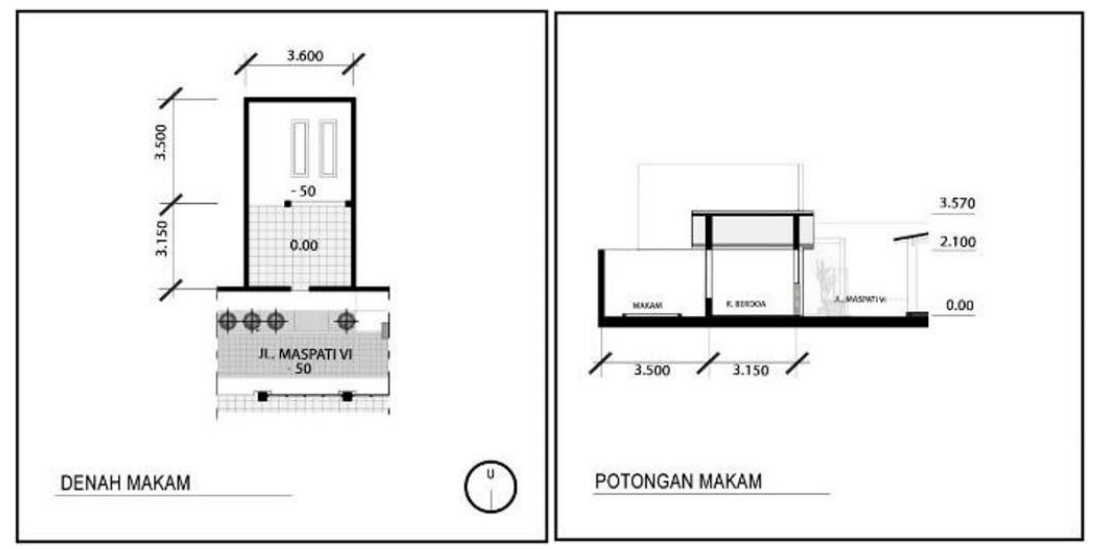

Gambar 27 Gambar Terukur Shelter

Sumber : Dokmentasi penulis

\subsection{KAMPUNG PELANGI KENJERAN}

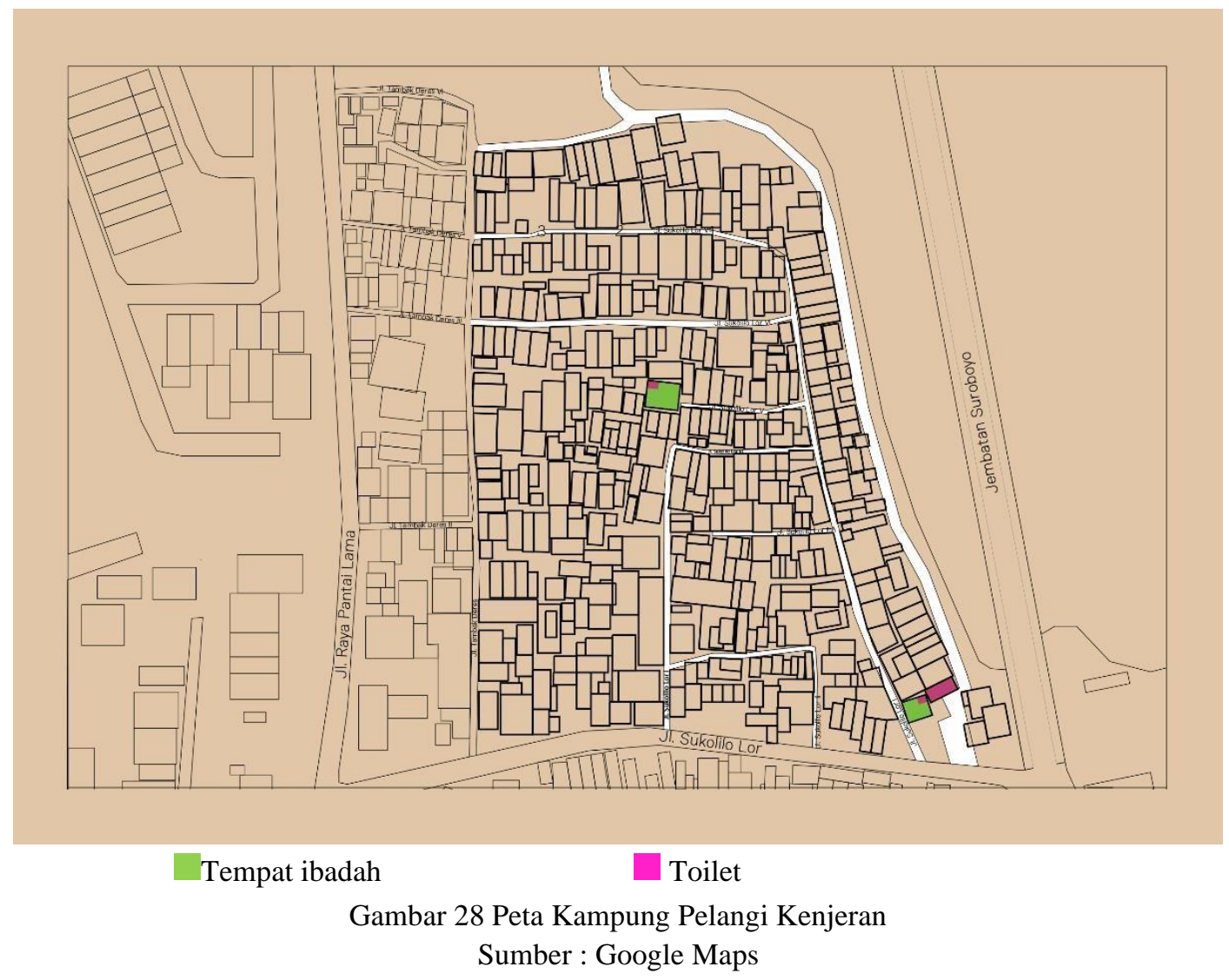

Kampung Pelangi Kenjeran merupakan hasil dari salah satu program Pemerintah Kota Surabaya, Kota Tanpa Kumuh (KOTAKU) karena kampung ini sebelumnya merupakan kampung yang kumuh dan tidak terawat, sehingga Pemerintah Kota Surabaya berupaya memperindah kampung ini dengan mengecat rumah-rumah pada kampung ini menjadi warnawarni. Selain untuk mengatasi kekumuhan, program tersebut juga bertujuan untuk mendukung destinasi wisata baru di Kota Surabaya, khususnya wilayah pesisir. M. Fisker selaku kepala Humas pemerintah Kota Surabaya menyebutkan pengecatan warna-warni pada dinding dan atap bertujuan untuk memberikan kesan unik pada kampung nelayan. Masyarakat pada kampung ini mayoritas berprofesi sebagai nelayan dan pedagang hasil laut berupa bahan 
pangan maupun souvenir. Namun tidak jarang para nelayan membantu wisatawan untuk pergi keliling ke laut untuk berwisata.

Kampung ini memiliki nama "pelangi" sebagai tema yang diangkat. Bila ditinjau mengenai pelangi itu sendiri, Al-Qarafi menjelaskan pelangi sebagai fenomena optik, pembiasan cahaya yang berasal dari air hujan yang terkena cahaya matahari. Dari hasil pembiasan tersebut membentuk busur dengan tujuh warna dasar (merah, jingga, kuning, hijau, biru, nila, ungu). Adanya warna-warna yang dihasilkan oleh pelangi tersebut menjadi ide yang diterapkan pada Kampung Pelangi Kenjeran.

Sebelum menjadi kampung pelangi, kampung ini merupakan permukiman nelayan, di mana warga sebagaian besar berprofesi nelayan pergi ke laut untuk mencari hasil laut seperti ikan, kerang, kepiting, dan lainnya untuk dijual dijadikan bahan makanan maupun souvenir. Umumnya kampung nelayan identik dengan lingkungan kumuh, bau, dan berantakan, termasuk Kampung Pelangi Kenjeran sebelum dijalankannya program KOTAKU. Berdasarkan keterangan dari www.kotaku.pu.go.id, program tersebut merupakan upaya untuk menangani kekumuhan yang ada pada kampung ini, beberapa upaya diantaranya dengan memberi perkerasan (paving block) pada jalan dan gang, perbaikan saluran drainase, pengadaan pot tanaman, depan rumah, dan pengadaan IPAL. Untuk menambah estetika dan menarik perhatian, bangunan-bangunan yang terdapat pada kampung ini dicat warna-warni baik dinding, dan atapnya termasuk ruang publik seperti koridor jalan dan lapangan.

Bila dilihat dalam cakupan wilayah yang lebih luas, adanya Kampung Pelangi Kenjeran yang disebut sebagai objek wisata tidak terlepas dari peran objek-objek di sekitarnya seperti Jembatan Suroboyo, Pantai Kenjeran Lama, dan Taman Air Mancur Menari. Dengan dijadikannya Kampung Kenjeran sebagai kampung pelangi, kampung ini memiliki kesamaan visual terhadap lingkungan sekitarnya sehingga membentuk kawasan yang memiliki karakter warna-warni.

Jika dilihat dari Jembatan Suroboyo Kampung Pelangi Kenjeran mencerminkan Pelangi yang dimaksud seperti tema yang ditawarkan. Namun yang perlu diteliti lebih lanjut, bagaimana tema "pelangi" diterapkan pada elemen- elemen lainnya dan seberapa besar bukti yang menunjukan adanya tema 'pelangi' pada Kampung pelangi Kenjeran. Berdasarkan potensi tersebut, selain karena program pemerintah, tempat ini juga dijadikan destinasi wisata oleh masyarakat. 


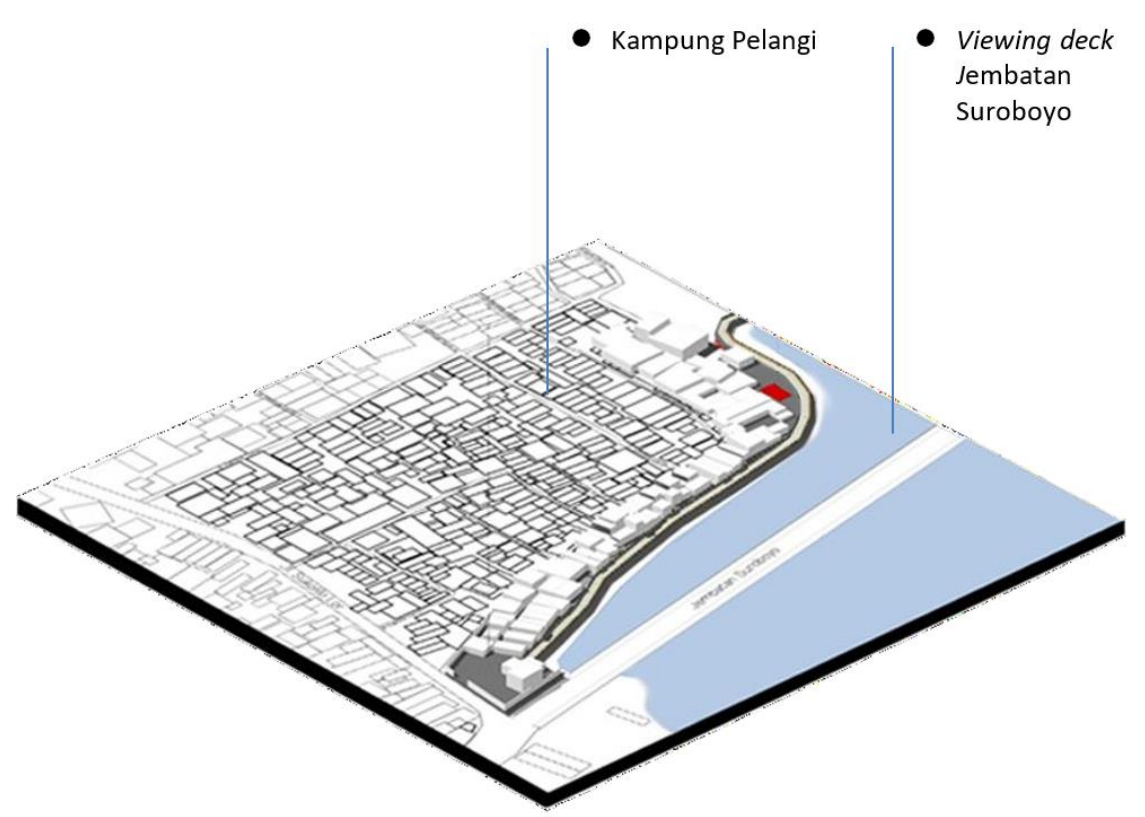

Gambar 29 Infrastruktur Baru Area Tepi Pantai

Sumber: Dokumentasi Penulis

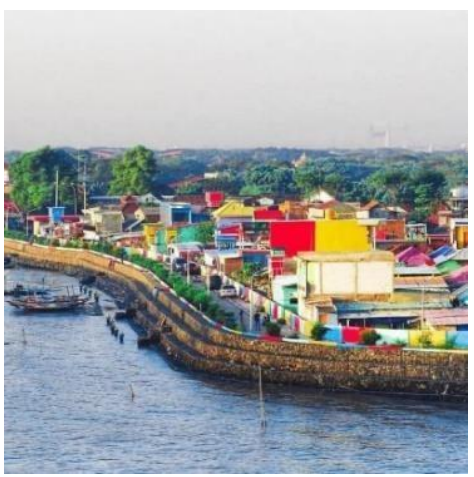

Gambar 30 Area parkir Survey: 14 Oktober 2020

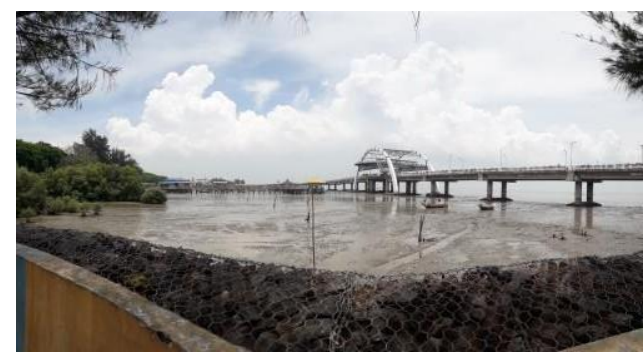

Gambar 31 Area parkir Survey: 14 Oktober 2020

Pada Kampung Pelangi Kenjeran, tidak terdapat aktivias wisata yang secara eksplisit diselenggarakan oleh pengelola setempat. Namun Kampung Pelangi Kenjeran memiliki potensi wisata karena lokasinya yang berada di dekat laut, hal tersebut menjadi daya tarik tersendiri bagi orang-orang untuk mengunjungi Kampung Pelangi Kenjeran terutama pada bagian jalan tepi pantai.

Sesuai dengan pernyataan Afdolu Nasikin, Senior Fasilitator Kota Surabaya, untuk menghilangkan kekumuhan dan mempercantik Kawasan maka dilakukan pembenahan pada wilayah Kenjeran, termasuk Kampung Pelangi Kenjeran. Dengan membangun jalan inspeksi tepi pantai, taman, pembenahan saluran air dan drainase dan jalan gang. Adanya pembangunan jalan di area tepi pantai membuat susasana lingkungan menjadi tertata. Koridor jalan ini juga berfungsi menghubungkan area lapangan parkir dekat Jl. Sukolilo Lor dengan area lapangan olahraga yang berada di dekat Pantai Kenjeran Lama. Hal tersebut mempermudah aksesibilitas baik bagi kendaraan maupun pejaan kaki dari luar sehingga memungkinkan adanya aktivitas baru seperti bazar dan pasar malam setiap bulan. 
Secara visual elemen seperti dinding dan jalan memiliki kesamaan dengan ruang terbuka yang berada di dekat persimpangan Jl. Sukolilo Lor, adanya cat warna-warni dengan pola vertikal sehingga turut membangun image kawasan sebagai kampung pelangi.

\section{KESIMPULAN}

Hadirnya kampung wisata pada kampung kota merupakan inovasi yang dilakukan baik oleh pengelola swasta maupun pemerintah. Tema wisata yang dihadirkan pada kampung wisata pun beragam, bergantung pada latar belakang dan tujuan masing-masing kampung.

Kampung Lawas Maspati memiliki tema "lawas" sebagai daya daya tarik wisata yang diangkatnya. Terdapat beberapa hal yang membuat Kampung Lawas Maspati memiliki suasana Indonesia lawas, yaitu dengan adanya sejumlah bangunan dengan arsitektur gaya Belanda yang ada di Indonesia pada awal tahun 1900an. Bangunan-bangunan tersebut ada yang masih utuh dan terawat, ada juga yang tidak. Ada beberapa bangunan lawas yang digunakan kembali dengan fungsi berbeda seperti café dan losmen. Aktivitas wisata yang dilakukan di koridor jalan seperti bermain permainan tradisional, adanya pertunjukan seni musik dan tari tradisional, dan suguhan makanan tradisional membuat suasana Indonesia tempo dulu semakin terasa.

Adanya seluruh kegiatan wisata tersebut diakomodir oleh elemen fisik yang memadai seperti adanya shelter untuk tempat beristirahat, papan penanda agar wisatawan tidak bingung, fasilitas akomodasi, dan sebagainya. Adanya elmen fisik (arsitektur) tersebut menjadi sebuah bukti adanya aktivitas wisata yang diwadahi pada kampung ini.

Lain halnya dengan Kampung Pelangi Kenjeran. Kampung ini memang terlihat warnawarni seperti warna-warna yang dimiliki pelangi jika dilihat dari luar kampung, di mana Jembatan Suroboyo merupakan spot khusus bagi wisatawan yang ingin melihat penampakan Kampung Pelangi Kenjeran secara utuh. Jalan tepi pantai pada Kampung Pelangi kenjeran menjadi wajah bagi kampung ini karena selain masih terlihat karakternya sebagai kampung pelangi, juga sebagai tempat beraktivitas yang dominan bagi wisatawan baik untuk sekedar melihat-lihat pemandangan laut sekitar maupun tempat berlabuh untuk melaut bersama nelayan. Jika menyusuri ke bagian dalam Kampung Pelangi Kenjeran, kampung ini belum mencerminkan tema "pelangi" yang diangkat sebagai daya tarik wisata yang diangkatnya. Suasana pada bagian dalam kampung pun tidak memiliki karakter yang spesifik baik secara visual maupun atribut fisiknya.

Tidak terdapat banyak bukti fisik yang ditemukan pada Kampung Pelangi Kenjeran yang mewadahi fungsinya sebagai kampung wisata. Namun dengan adanya fasilitas koridor jalan tepi pantai cukup membantu pengunjung yang ingin menikmati pemandangan laut setempat. Adapun tersedianya lapangan olah raga selain untuk kebutuhan olahraga warga kampung juga biasanya digunakan untuk tempat bazar yang diselenggarakan satu bulan sekali. Adanya jalan tepi pantai memudahkan akses seperti kendaraan untuk bongkar muat dari Jl. Sukolilo Lor ke Lapangan olahraga.

Dari aspek something to see, something to do, dan something to buy, Kampung Lawas Maspati memenuhi ketiga kriteria tersebut. Sedangkan Kampung Pelangi Kenjeran memiliki kecenderungan hanya sebagai objek untuk dilihat (something to see). Dengan demikian adanya elemen fisik sangat berperan dalam menunjukan eksistensi suatu kampung wisata. 
Hadirnya kampung wisata terbukti dapat merubah wajah kampung baik dari segi fisik, sosial, budaya, dan ekonomi. Namun agar tercipta kampung wisata secara optimal, sebaiknya perlu ditinjau terlebih dahulu bagaimana latar belakang kampung tersebut, sehingga dapat diketahui potensi apa yang dapat dikembangakan untuk dijadikan wisata. Adanya elemen fisik (arsitektur) tentu menjadi hal penting untuk mewadahi kegiatan wisata yang berlangsung agar aktivitas wisata yang dilakukan pada kampung tersebut menjadi berkelanjutan.

\section{DAFTAR PUSTAKA}

CHING, Francis D.K. 1979. Architecture: Form, Space, And Order

COLOMBIJN, F. Kampung Perkotaan Indonesia: Kajian Historis-Antropologis Terhadap Kesenjangan Sosial Dan Ruang Kota

IKAPUTRA, Dkk. 2020. Morfologi Urban Artefak Kampung Kota. Jurnal Ilmiah Penelitian Marka.

ISTOC, E. Urban Cultural Tourism And Sustainable Development. International Journal For Responsible Tourism - Vol. 1, No. 1

LARASATI, R. 2017. Strategi Pengembangan Pariwisata Budaya Yang Berkelanjutan Pada Kampung Lawas Maspati Kota Surabaya. Surabaya: DEPARTEMEN PERENCANAAN WILAYAH DAN KOTA Fakultas Teknik Sipil Dan Perencanaan Institut Teknologi Sepuluh Nopember

LYNCH, K. 1960. The Image Of The City.

YOETI. 1996. Pengantar Ilmu Pariwisata, Edisi Revisi. Bandung : ANGKASA RAPOPORT, Amos. Human Aspects Of Urban Form. 1977. PERGAMON PRESS WIDJADJA, P. 2013. Kampung Kota Bandung. Yogyakarta: Graha Ilmu

Internet:

https://www.bbc.com/indonesia/majalah/2016/10/161016_majalah_kampung_warna_warni_malang https://docplayer.info/52292689-Kampoeng-lawas-maspati.html

https://www.youtube.com/results?search_query=kampung+lawas+maspati 